\title{
City of Jiangsu Province Tourism Industry System Construction Analysis
}

\author{
Yaping Wang ${ }^{1, a}$ \\ ${ }^{1}$ Xi'an International University, Xi'an, Shaanxi, 710077 \\ ${ }^{\mathrm{a}}$ email
}

Keywords: Index of the Monopoly, The First Degree, Tourism Industry, Jiangsu Province

\begin{abstract}
According to the theory of six elements in tourism and urban tourism competitiveness theory, to construct a system of urban tourism industry structure model, from tourism, investment, tourism resources, tourist traffic, tourist hotels, travel agencies, tourist performance and so on six aspects, the 1317 cities in jiangsu province tourism monopoly index and the first index to measure, found in suzhou tourism monopoly index and the first index, a city alone. Keeps abreast of domestic travel in nanjing and suzhou. Hope that through in-depth analysis of tourism development in jiangsu province, and puts forward corresponding countermeasures, promote the overall development of the global tourism in jiangsu province.
\end{abstract}

\section{Introduction}

Research on urban tourism industry system is at home and abroad has a lot of results. 1939 Jefferson in Urban scale - rank theory presented during the city's first law (Law of the primate city) concept], causing academia urban scale - multilevel rank Theory. Ades and Glaesser factors influencing the degree of urban primacy that political factors are more important than economic factors. Hall proposed infrastructure and socio-economic development among different regions will make the tourism regional tourism development scale appears difference. Our recent research into the centralized system of urban industrial period, the city on the first degree studies, Yu seeking British study found that by comparing the capital city of China's first 18-degree greater than 2 . The concept of the first degree and after the introduction of the first cities in China, in the field of urban tourism research unfolds study Chinese mainland provinces class city of tourism development through differences in scale and size distribution of rank theory, but most studies mainly in tourist traffic and tourism income as an indicator to measure, and not from the tourism industry influencing factors to consider tourism value, the paper draw professor Sun Gennian city tourism dominate the evaluation system, six factors (tourism resources, tourism investment, tourism, transportation, tourist hotels, travel agencies, tourism performance), Jiangsu Province, the tourism industry system are comprehensive analysis, and for the differences in scale proposed optimization measures.

China's tourism industry development stage is in a steady increase in the development stage, the Government adopted a number of favorable policies to promote the tourism industry continue are to adjust the system, the tourism industry occupies an increasingly important share of the total industrial output value in the provinces. China's economically developed provinces, accounting for government priority development policy advantages, traffic artery advantages, location advantages, government investment and other investment advantages, and lay a solid foundation for tourism branding, tourism and establish a good image.

\section{Conceptual Model and data sources}

Tourism industry is driven by a very strong comprehensive industrial clusters, different scale regional scale tourism development, which means that regional tourism evolutionary path is not the same, so the only tourist traffic and tourism income to measure the development of tourism is not comprehensive This requires a variety of methods to study the differences between the scale of the development of regional tourism - based on the theory of six elements of tourism and city tourism 
competitiveness theory, Mr. Sun has established urban tourism industry system architecture modeling, the entire system including, tourism six investment, tourism resources, tourism, transportation, tourism, hotels, travel agencies, and other performance.

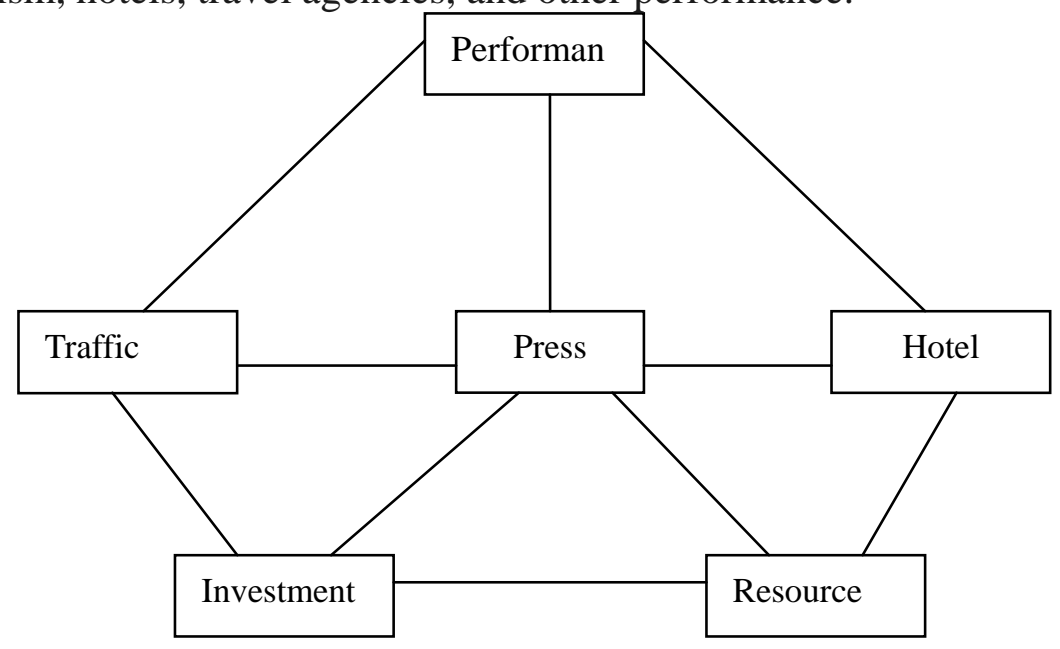

Tourism resources are the most basic tourism attraction factors, with the high level of tourism resources in order to attract attention to the relevant government departments to attract investment in tourism planning, tourism planning scientific and rational, large-scale tourism investment, improve the tourism traffic, increasing resort the accessibility, supporting the construction of hotels, restaurants, travel agencies, making the development of the basic elements of a regional tourism has been improved. Travel circuit design, marketing, to attract popularity, after the arrival of tourists travel spending, gathering wealth, further increasing the economic, social and environmental benefits of tourism resources of the region lies.

Travel six elements interconnected system, has its own value, six elements complement each other, influence each other, to attract popularity, gathering wealth for the industry to contribute to a regional tourism.

\section{Tourism Industry Measurement System of 13 Cities in Jiangsu Province}

Jiangsu Province, the overall economic development of tourism, 13 prefecture-level cities have their own characteristics, from the point of view of urban geography, tourism has been formed to Suzhou in Jiangsu as a leader, Nanjing, Wuxi for the two wings of the development pattern.

According monopoly index measurement, the most abundant resource in Suzhou monopoly index of $14.80 \%$, less than $35 \%$, the proportion of the province's small, a low concentration of competitive resources Suzhou first index of 1.56, comparison with other cities is not obvious, it is the first low. Informed that monopoly system and the first index of Jiangsu tourism resources is not high, belonging to the province relatively balanced distribution of urban resources, more balanced regional development within provinces by both measure analysis.

Table 1 cities in Jiangsu Province tourism resources and industrial investment capacity

\begin{tabular}{llllllllllllllll}
\hline Project & $\begin{array}{l}\text { Nanji } \\
\text { ng }\end{array}$ & Wuxi & $\begin{array}{l}\text { Xuzho } \\
\mathrm{u}\end{array}$ & $\begin{array}{l}\text { Chang } \\
\text { zhou }\end{array}$ & $\begin{array}{l}\text { Suzho } \\
\mathrm{u}\end{array}$ & $\begin{array}{l}\text { Nant } \\
\text { ong }\end{array}$ & $\begin{array}{l}\text { Lian } \\
\text { yung } \\
\text { ang }\end{array}$ & $\begin{array}{l}\text { Huai } \\
\text { an }\end{array}$ & $\begin{array}{l}\text { Yanc } \\
\text { heng }\end{array}$ & $\begin{array}{l}\text { Yang } \\
\text { zhou }\end{array}$ & $\begin{array}{l}\text { Zhen } \\
\text { jian } \\
\text { g }\end{array}$ & $\begin{array}{l}\text { Taizh } \\
\text { ou }\end{array}$ & $\begin{array}{l}\text { Suqi } \\
\text { an }\end{array}$ \\
$\begin{array}{l}\text { Resource } \\
\text { abundance } \\
\text { market share }\end{array}$ & 90.25 & 104.75 & 106 & 52.25 & 136 & 69.5 & 64.5 & 57.5 & 53.5 & 55 & 46.5 & 43.75 & 39.5 \\
& 9.82 & 11.40 & 11.53 & 5.69 & 14.80 & 7.56 & 7.02 & 6.26 & 5.82 & 5.98 & 5.06 & 4.76 & 4.30 \\
$\begin{array}{l}\text { Tourism } \\
\begin{array}{l}\text { Investment } \\
\text { (milion) }\end{array}\end{array}$ & 3919 & 3429 & 3084 & 2473 & 4636 & 3214 & 1267 & 999 & 2287 & 1948 & 1849 & 1829 & 1217 \\
market share & 12.19 & 10.67 & 9.59 & 7.7 & 14.42 & 10 & 3.94 & 3.12 & 7.11 & 6.06 & 5.75 & 5.69 & 3.76 \\
\hline
\end{tabular}

* A level and above cities to resort to calculate the abundance of tourism resources, the tertiary industry investment alternatives around the city

Tourism investment is the local government in order to develop tourism, financial support in the development of tourism resources, improve the tourism infrastructure, the expansion of tourism 
effect and maintain the normal operation of the tourism industry, etc. provided, is for regional tourism development funding and conditions, relevant literature find the most relevant tertiary industry and tourism. Therefore, this article uses as an alternative investment in the tertiary industry index for each city tourism investment. As can be seen from a table, Jiangsu Province, the third industrial investment is large, especially in Suzhou and Nanjing in the first two tourism investment, respectively $14.42 \%$ and $12.19 \%$. Suzhou abundance of large, we need to invest in construction projects than the more, Nanjing is the deputy provincial capital cities around the country brought together resources, investment and construction efforts to clear. Wuxi and Xuzhou is an emerging development of the city, the government gradually increased investment in all sectors, promoting balanced regional economic development in Jiangsu Province. The overall analysis, because the southern Jiangsu, Suzhou and Nanjing, two major cities in the area drive of the larger, so the investment is the leader, followed by the Soviet Union, North Jiangsu weakest. This is further reflected in regional imbalances and differences in Jiangsu province's economic strength development. The calculated index monopoly Suzhou tourism investment was $14.42 \%, 12.19 \%$ of Nanjing, less than 35\%, a monopoly weaker city. The first index is 2 of Suzhou, Nanjing 1.67. Simply look at the amount of investment in each city of Suzhou and Nanjing are always at the forefront of the province, but belong to the economically developed areas in Jiangsu Province, the province's economic development more balanced, tourism investment is relatively balanced Therefore monopoly index and the first index is not obvious.

Table 2 is around the city, Jiangsu Province, passenger transport volume and market share. Nanjing Lukou International Airport is the third largest international airport in East China, is China's major trunk airport, ranked the ten million ranks of major airports, national, regional transport hub. 2009 annual passenger throughput is more than million. It ranked second in the annual passenger volume Wuxi Airport only 1/4 of Nanjing, Jiangsu city airport are domestic regional airports, in addition to limited throughput Wuxi outside. Nanjing in Jiangsu Province has the highest air passenger dominate sex characteristics, including monopoly index up 60.66 percent, belong to high monopoly, the first index B 18.5, the first very high degree. Nanjing, the capital city as a dominate advantage in air traffic in the outstanding performance, reflecting the unique political center.

2014 in Jiangsu province's railway passenger traffic of up to 18522 people, Suzhou City passenger traffic up to 6919 million, accounting for 37.36\% of Jiangsu province's railway passenger traffic, passenger traffic in Nanjing is 3844 million, accounting for $20.75 \%$, the two cities railway passenger sources accounted for more than over 50\%, which is the regional hub for rail traffic in Jiangsu province. Other cities are ranked in Xuzhou, Wuxi, Changzhou, Zhenjiang, Yancheng, Lianyungang, Nantong, Taizhou, Huai'an, In 13 cities, the city of Suzhou railway passenger first degree B is 7.2, a high degree of concentration.

With the improvement of China's road transport network, the implementation of policies and holidays free passage of large quantities of private car owners choose to travel by car, which further promote China's domestic tourism boom, so the road passenger traffic in Jiangsu province in passenger traffic accounting for up to 87\%. 2014 total customer base amounted to 137,270 million, reflecting the importance of road passenger transport in Jiangsu Province. Highway Tourist amount of Suzhou in Jiangsu province has dominated, monopolistic index up 28.73 percent, ranking the second in the city of Xuzhou in northern Jiangsu traffic artery connecting Suzhou and other provinces highway traffic. Since air and rail Nanjing convenience, road transport ranked third, and his traffic location in the province related conditions. Suzhou, Jiangsu province in the first degree road transport 4.8.

III integrated transportation aviation, railways, highways, according to the equation (6) Calculation of Jiangsu Province city's comprehensive transportation capacity of 13, which is weighted overlay Suzhou City 126739700 passengers, monopoly index was $29.32 \%$, the first index of B 5. Thus traffic area of Suzhou in Jiangsu Province, has the advantage of dominating nature. It is highly concentrated type of traffic advantage. 
Table 2 cities in Jiangsu traffic passenger volume and market share

\begin{tabular}{|c|c|c|c|c|c|c|c|c|c|c|c|c|c|c|}
\hline & Project & $\begin{array}{l}\text { Nanji } \\
\text { ng }\end{array}$ & Wuxi & $\begin{array}{l}\text { Xuzho } \\
\text { u }\end{array}$ & $\begin{array}{l}\text { Chang } \\
\text { zhou }\end{array}$ & $\begin{array}{l}\text { Suzho } \\
\mathrm{u}\end{array}$ & $\begin{array}{l}\text { Nanto } \\
\text { ng }\end{array}$ & $\begin{array}{l}\text { Liany } \\
\text { ungan } \\
\mathrm{g}\end{array}$ & $\begin{array}{l}\text { Huaia } \\
\mathrm{n}\end{array}$ & $\begin{array}{l}\text { Yanch } \\
\text { eng }\end{array}$ & $\begin{array}{l}\text { Yangz } \\
\text { hou }\end{array}$ & $\begin{array}{l}\text { Zhenj } \\
\text { iang }\end{array}$ & $\begin{array}{l}\text { Taizh } \\
\text { ou }\end{array}$ & $\begin{array}{l}\text { Suqia } \\
\mathrm{n}\end{array}$ \\
\hline $\begin{array}{l}\text { aviat } \\
\text { ion }\end{array}$ & $\begin{array}{l}\text { The amount of } \\
\text { tourists } \\
\text { people } \\
\text { market share\% }\end{array}$ & $\begin{array}{l}1628 \\
60.66\end{array}$ & $\begin{array}{l}418 \\
15.57\end{array}$ & $\begin{array}{l}127 \\
4.73\end{array}$ & $\begin{array}{l}186 \\
6.93\end{array}$ & & 3. 46 & 2.12 & 1.94 & 1.94 & $\begin{array}{l}71 \\
2.65\end{array}$ & & & \\
\hline $\begin{array}{l}\text { rai } \\
\text { lwa }\end{array}$ & $\begin{array}{l}\text { The amount of } \\
\text { tourists }\end{array}$ & 3844 & 1900 & 2093 & 1333 & 6919 & 253 & 294 & 200 & 220 & 142 & 1029 & 240 & 55 \\
\hline y & $\begin{array}{l}\text { people } \\
\text { market share\% }\end{array}$ & 20.75 & 10.26 & 11.30 & 7. 20 & 37.36 & 1. 37 & 1. 59 & 1.08 & 1.89 & 0.77 & 5.55 & 1.30 & 0.3 \\
\hline $\begin{array}{l}\text { hig } \\
\text { hwa }\end{array}$ & $\begin{array}{l}\text { The amount of } \\
\text { tourists / }\end{array}$ & 10596 & 7222 & 15063 & 6769 & 39432 & 9998 & 5433 & 8435 & 9440 & 4792 & 4461 & 8895 & 6734 \\
\hline y & $\begin{array}{l}\text { people } \\
\text { market share\% }\end{array}$ & 7. 72 & 5.26 & 11 & 4. 93 & 28.73 & 7.28 & 3.96 & 6.14 & 6.88 & 3. 49 & 3.25 & 6.48 & 4. 90 \\
\hline & $\begin{array}{l}\text { Weights / } \\
\text { people } \\
\text { market share }\end{array}$ & $\begin{array}{l}4734 . \\
9 \\
10.95\end{array}$ & $\begin{array}{l}2705 . \\
7 \\
6.26\end{array}$ & $\begin{array}{l}4698 . \\
4 \\
1087\end{array}$ & $\begin{array}{l}2299 . \\
5.32\end{array}$ & $\begin{array}{l}12674 \\
29.32\end{array}$ & $\begin{array}{l}2724 . \\
6.30\end{array}$ & $\begin{array}{l}153 \\
3.56\end{array}$ & $\begin{array}{l}2283 \\
5.28\end{array}$ & $\begin{array}{l}2552 \\
5.90\end{array}$ & $\begin{array}{l}1323 \\
3.06\end{array}$ & $\begin{array}{l}1520 \\
3.52\end{array}$ & $\begin{array}{l}2397 \\
5.54\end{array}$ & $\begin{array}{l}1770 \\
4.10\end{array}$ \\
\hline
\end{tabular}

Travel Agencies, Hotels and Reception Capacity Measurement. Travel agencies are six elements of tourism connected link, coordination and communication play a role in tourism activities. Since the construction of airports and other related facilities, the tourist center of Nanjing, Jiangsu Province, has become so numerous agencies, can be seen from Table 3, the number of travel agencies in Nanjing as high as 576 , monopoly index $25.6 \%$, are in focus degree centralized. B is the first index of 3.1, the first distribution is moderate.

Hotels and restaurants is one of the economic indicators of a developed city, also a board to protect the city's export-oriented economic development, not only to protect the basic capabilities of a tour to meet the tourists demand tourist destinations overnight, while a tourism drive the rapid development of related industries. Jiangsu Province, the number of hotels and restaurants statistics, the top four are in Suzhou, Xuzhou, Nanjing, Nantong four cities, including Suzhou and Nanjing are rapid economic development of tourism as the representative of the city, Nantong and Xuzhou is a Port City export-oriented economy as the representative of the city. Other cities have tourist hotels and the level of tourism development in the region about the amount. The overall index and the first degree of monopoly is not obvious.

Table 3 cities in Jiangsu Province travel agencies and hotels reception capacity

\begin{tabular}{|c|c|c|c|c|c|c|c|c|c|c|c|c|c|}
\hline Project & $\begin{array}{l}\text { Nan ji } \\
\text { ng }\end{array}$ & Wuxi & Xuzhou & $\begin{array}{l}\text { Changz } \\
\text { hou }\end{array}$ & Suzhou & $\begin{array}{l}\text { Nanton } \\
\mathrm{g}\end{array}$ & $\begin{array}{l}\text { Lianyu } \\
\text { ngang }\end{array}$ & Huaian & $\begin{array}{l}\text { Yanche } \\
\text { ng }\end{array}$ & $\begin{array}{l}\text { Yangzh } \\
\text { ou }\end{array}$ & $\begin{array}{l}\text { Zhenji } \\
\text { ang }\end{array}$ & $\begin{array}{l}\text { Taizho } \\
\text { u }\end{array}$ & Suqian \\
\hline $\begin{array}{l}\text { Travel } \\
\text { Quantity }\end{array}$ & 576 & 165 & 191 & 129 & 288 & 140 & 113 & 103 & 136 & 126 & 103 & 114 & 67 \\
\hline Share & 25.6 & 7. 33 & 8. 48 & 5.73 & 12. 79 & 6.22 & 5.02 & 4. 57 & 6.04 & 5.60 & 4. 57 & 5.06 & 2. 99 \\
\hline Hotels & 102 & 55 & 123 & 68 & 132 & 96 & 44 & 48 & 49 & 63 & 38 & 29 & 26 \\
\hline Share & 11.68 & 6.30 & 14. 09 & 7. 79 & 15.12 & 11 & 5.04 & 5.50 & 5.61 & 7. 22 & 4. 35 & 3. 32 & 2.98 \\
\hline
\end{tabular}

\section{Comprehensive Analysis}

Chinese tourism in the process of development, high-quality tourism resources is a direct factor in attracting tourists to tourist destinations, Jiangsu Province, located in the Yangtze River Delta economic developed areas, are ranked China Comprehensive Regional Tourism Development in the previous provinces. In this paper, index monopoly and urban primacy index by Jiangsu Province 13 prefecture-level cities rich in tourism resources, further tourism investment, tourism, passenger transportation, tourism, hotels, travel agencies and tourist traffic, tourism income and other indicators of the analysis, and to use tourist center parting rating scale model was constructed in Jiangsu Province tourism industry scale pyramid system, and hopes to further optimize the Jiangsu 
tourism industry development pattern.

Nanjing as the capital city holds first advantage in the political status, and therefore the development of tourism in addition to maintaining the existing dominant position outside the capital city, should continue to increase investment in tourism, the use of good urban management system and the positive development of business tourism infrastructure, MICE tourism, urban tourism and the surrounding rural tourism, to make up for the lack of tourism resources, and secondly to strengthen the image of the capital city of packaging publicity, not only in the country to create awareness, more importantly, create high-quality international image and attract more foreign visitors to Nanjing tourism and increase tourism foreign exchange earnings.

"Paradise on Earth" reputation of Suzhou, China is a high-quality tourism resources gathering place, especially with the strong backing of his city Shanghai formation of complementary advantages, tourist exchange, from Shanghai only 90KM, Shanghai international metropolis total inbound tourists in the nation, forming a large number of tourists overflow Suzhou, Suzhou City, led to the rapid growth of the total customer base. Suzhou City, should continue in the future course of development of advantageous resources, deepen the "Soviet-style garden" innovative development advantages of resources, training characteristics of Soviet-depth experience of the tourism industry, continue to build a new international tourism resort model has become Shanghai back garden, play a leading role in Suzhou, Jiangsu province, the leading tourism industry, tourists do receive simultaneously radiating the surrounding province, Wuxi, Nantong, Yangzhou and other cities the development of tourism, to form a good momentum of Jiangsu global integrated tourism development.

Wuxi City is a veteran industrial city, but also the emerging tourist city, outstanding performance in the development of tourism in recent years, Jiangsu Province, the tourism performance, followed by the government tourism investment capital of Nanjing, Jiangsu Province, is the future of leisure, entertainment, film and television industry leader in the development of the city. In the process of tourism development in Jiangsu Province, Wuxi, Nanjing, Suzhou River formation development model, Jiangsu led global integrated tourism development.

In this paper monopoly index, the first index of Jiangsu Province, 13 cities were quantitatively analyzed, but the data have stayed in the analysis of a certain time period, continuing research lack of time series, combined for temporal time series and spatial sequences analysis of the tourist center is the future direction of development of the city tourism industry research.

\section{Acknowledgements}

Fund project: the project of Shaanxi province department, 2015 sf297 Shaanxi province urbanization development and the interaction research on economic growth.

\section{References}

[1] Jefferson M. The Law of primate city [J]. Geographical Review, 1939, 29: 226. 332

[2] Ellison G. The determinants of geographic concentration [J]. American Economic Review Papers and Proceedings, 1999(2), 311-316

[3] Hall C, Page S. The geograghy of tourisms and recreation: Environment, space and place [M]. London; Routledge

[4] Qiu Yuyng. China's first provincial-degree study [D]. Shanghai East China Normal University, College of Resources and Environmental Sciences, 2014

[5] Li Hong, Sun Genlin. The city of Xi'an in Shaanxi Tourism dominate: An Analysis Based Industry System [J]. Shaanxi Normal University (Natural Science), 2016.44 (2): 91-97

[6] Sun Gennian. P the regional differences pimpin X. District of Shaanxi Tourism Development and its influencing factors [J]. Arid Land Resources and Environment, 2013, 11 (27; 184-191)

[7] Pang Wen, Ma Yaofeng. Fractal and fractal dimension Tourist Flow Size Distribution - A Case 
Study of Inbound Tourism [J]. Northwest University (Natural Science), 2010.40 (5): 905-909

[8] Lichuan Wu, Zhang Xiaolin, Wu Wei. Based on Fractal Theory of the Urban System of Jiangsu Province [J]. Resources and Environment in the Yangtze Basin, 2010, 19 (1): 1-6.

[9] Zhao Lei, Wang Yonggang, Zhang Lei. Differences in scale study tour in Jiangsu Province and rank scale system [J]. Economic Geography, 2011, 31 (9): 15766-1571. 